\title{
安全システムにおけるボルト緩みの可視化機構の開発
}

\author{
千葉 正伸*1，市川 修*1，中村 瑞穂"1，杉本 旭*2，鞍田 崇*3
}

\section{Development of a safety visualization mechanism for bolt looseness}

\author{
Masanobu CHIBA $^{* 1}$, Osamu ICHIKAWA ${ }^{* 1}$, Mizuho NAKAMURA ${ }^{* 1}$, Noboru SUGIMOTO*2 \\ and Takashi KURATA*3 \\ ${ }^{* 1}$ Polytechnic University \\ 2-32-1 Ogawa-nishimachi, Kodaira-shi,Tokyo 187-0035, Japan \\ ${ }^{*}$ Nagaoka University of Technology, Graduate School of Engineering \\ 1603-1 Kamitomioka-machi,Nagaoka-shi,Niigata 940-2188, Japan \\ ${ }^{* 3}$ Meiji University, Graduate School of Science and Technology \\ 1-1-1 Higashi-mita, Tama-ku, Kawasaki-shi,Kanagawa 214-8571, Japan
}

Received: 6 December 2016; Revised: 15 February 2017; Accepted: 14 April 2017

\begin{abstract}
Bolts are loosened by various external forces applied to them and due to their aging degradation. Bolt looseness has caused an unending stream of serious accidents and disasters. In order to prevent accidents due to bolt looseness, visual inspection is still important and indispensable at present. On the other hand, though periodic inspection of some mechanical equipment has been obligated by law, most daily inspection before starting operation and the like are reliant on visual inspection. Inspection in this mode can detect bolt omission and other major changes, but cannot detect minor bolt looseness. Suitably, the visual inspection cannot grasp as far as progress in bolt looseness, either. In view of this, as time advances, bolt looseness develops, which often leads to serious accidents. In this research, a mechanism for the precisely visualization of an imperceptible bolt looseness and the grasp of the degree of bolt looseness was developed. Apart from the requisite inspection of bolts, this mechanism can confirm the progress in bolt looseness, and detect the bolt looseness over the preset amount of the minimum permissible bolt looseness through the behavior of the axial force detecting pin. The visualization mechanism is composed of positive components, and is formed to be safety confirmation type, so that it can precisely transmit and alert bolt looseness. Featured by the preciseness and efficiency in bolt looseness checking, the visualization mechanism is intended to prevent accidents.
\end{abstract}

Key words : Safety, Risk assessment, Fail safe, Safety manegiment, Safety inspection, Bolt looseness

\section{1. 緒言}

ボルトによる締結は，スパナによる簡単な締め付けで大きな締結力(軸力)が得られる利点がある。これは安価 なこともあり，広範囲に使用されている現状がある。しかし，ボルト締結体に様々な外力が加わると，時間経過 とともに緩みが誘発され，この緩みに起因する事故，災害に至ったケースが数多く報告されている(朝日新聞， 2012a，2012b)(国土交通省，2015)。ボルトの緩みを大別すると，ボルトが回転する「回転緩み」と締結体の塑性 変形による「へたり緩み」に分けられる，回転緩みに対する防止策として，各メーカーで出されているものもあ るが(若林，2013)完全な予防を保証するものはないのが現状である.

ボルトの締結体は，安全工学上，その機能を持続する機能的安全が求められる((社)日本労衝安全衛生コンサル タント会，2000)。これを実現するには，緩み発生と同時に自動的に増し締めを行う「物」が必要となるが，この ような「物」はまだ出現していない，そのためボルト締結体の安全管理は人間である「者」に委ねるところとな

\footnotetext{
No.16-00548[DOI:10.1299/transjsme.16-00548], J-STAGE Advance Publication date: 26 April, 2017

${ }^{* 1}$ 正員，職業能力開発総合大学校（厂187-0035 東京都小平市小川西町 2-32-1）

*2 正員，フェロー，長岡技術科学大学 名誉教授（广940-2188 新潟県長岡市上富岡町 1603-1）

*3 明治大学大学院（广214-8571 神奈川県川崎市多摩区東三田 1-1-1）

E-mail of corresponding author: m-chiba@uitec.ac.jp
} 
る.ボルト緩みの目視点検は始業点検などでよく用いられるが，目視には限界があり，人が緩みの進行状況を把 握することは明らかに限界がある.

本研究では，ボルトの複合的な緩み点検管理のために，目視により「緩み」を正確に判断できる安全システム を構成するためのボルト緩みの可視化機構(以下，可視化機構と略す)の開発を行った．可視化機構は，緩みが，予 め設定した最小許容限界值に達したとき, ボルト緩み変位に対し数十倍の大きさに拡大した軸力検出ピン(以下, 検出ピン)の動作により，人間に危険を明示するものである．検出ピンはボルトが締まっている場合は突出し，緩 んだ場合は圧縮コイルばねにより押し戻され，ホルダ内に隠れる。可視化機構は，ボルトの緩みを伝達する安全 センサの役割を持つため, フェールセーフな安全システムが構成される. 緩みは, 2 重ナット(ダブルナット)で改 善されるが完全ではない. 2 重ナットの如何にかかわらず緩みに起因する事故の予防に適用される緩み可視化機 構の開発を目指し，本論文では，その構成を示すとともに，安全センサとしての条件，すなわち，安全の側(緩み を締める側)に対するボジティブな構造, および, 緩み側に対するノーマルクローズの構造(杉本, 蓬原, 1990a)を 持つ等, 安全確認型システム(杉本, 蓬原, 1990b) (杉本他, 1987)として実現されることを示寸. なお, 本研究で は，M16 ボルト(強度区分 4.8)に適用した試作例について示寸.

\section{2. 可視化機構の構成と緩み検出動作}

\section{$2 \cdot 1$ 可視化機構の構造と動作}

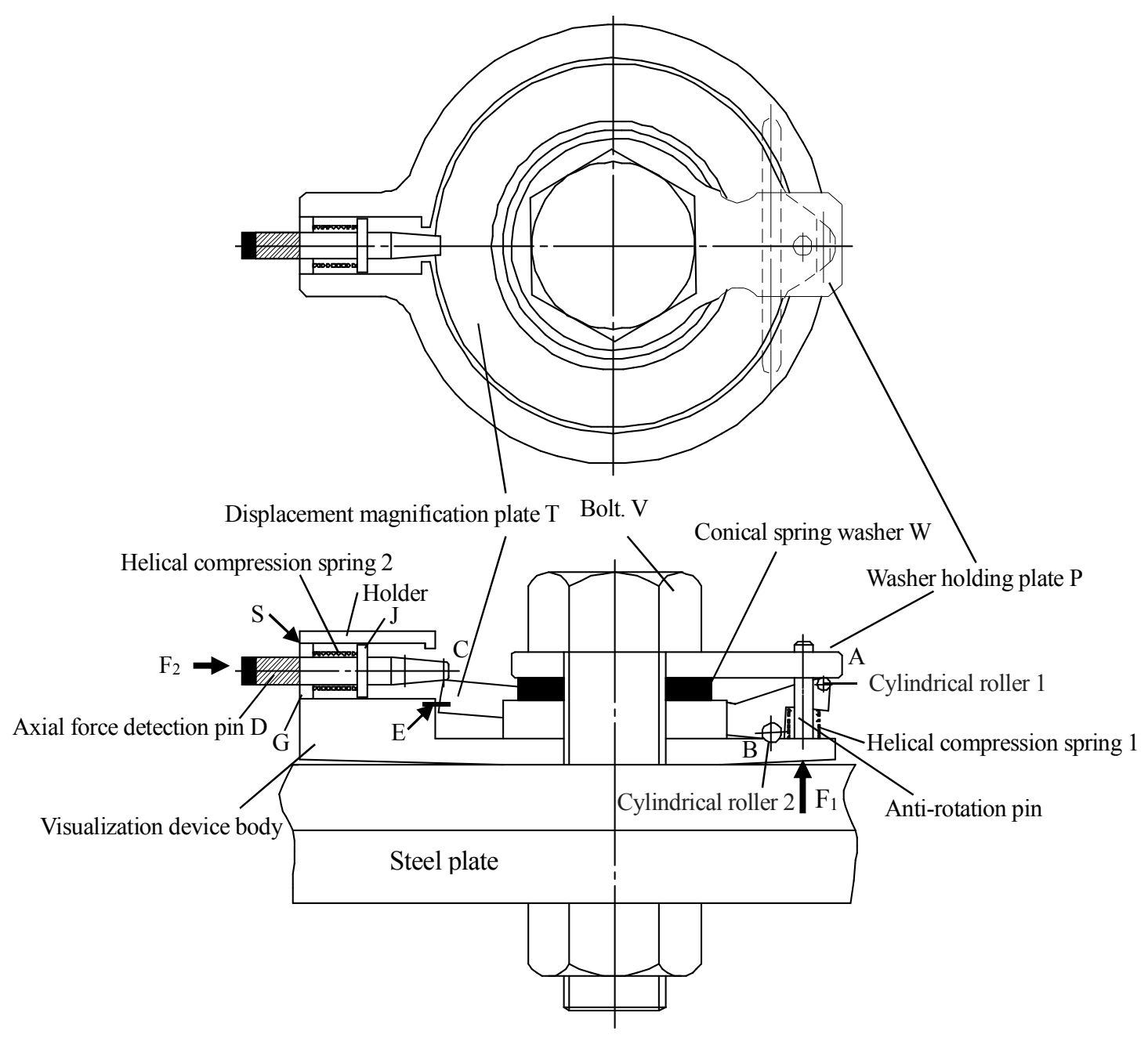

Fig. 1 Overall view of visualization mechanism. 
可視化機構の全体図(千葉他，2017)を図 1 に示す。ベース本体の中心部を締結ボルト V が通っており，可視化 機構の設置の手順は，はじめに検出ピン D を引出しておきボルト V を締める．その締め付け力は座金押さえ板 $\mathrm{P}$ を介し，皿ばね座金 $\mathrm{W}$ を圧縮する．同時に変位拡大板 $\mathrm{T} の \mathrm{~A}$ 点が押し下げられ $\mathrm{C}$ 点は上昇する．このとき圧 縮コイルばね 1 は圧縮されエネルギーが保持される． A 点及び支点となる $\mathrm{B}$ 点には摩擦抵抗低減のため円筒状 のころが組み込まれている．ただし， B 点におけるころは溝によっては回転自在であるが水平方向の動きが拘束 されている. かくして，最大許容軸力における検出ピン $\mathrm{D}$ の位置をテーパ部の $\mathrm{C}$ 点とすると，人間による締め 付け作業は, 目視しつつ最大許容軸力点 $\mathrm{E}$ 点までの締め付けを行い, 次に検出ピン $\mathrm{D}$ をテーパ部の $\mathrm{C}$ 点に添え ることである(緩み監視の起点の設定)，ただし，このとき検出ピン $\mathrm{D}$ の目印となる $\mathrm{S}$ 線で，最大許容軸力設定位 置を確認寸れば，特別な工具を用いることなく締め付け軸力の設定が可能となる.

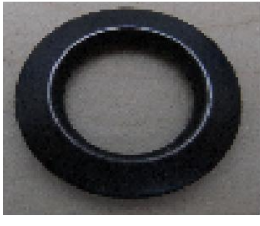

(a) Conical spring washer(Call 16).

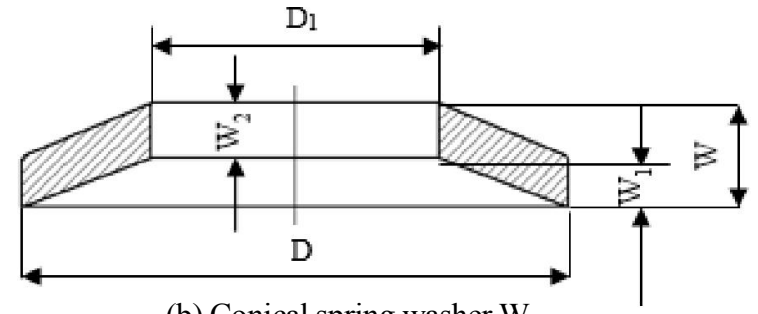

(b) Conical spring washer W.

Fig. 2 Conical spring washer W. (JIS 1species heavy load type H type.)

Axial force detection pin D

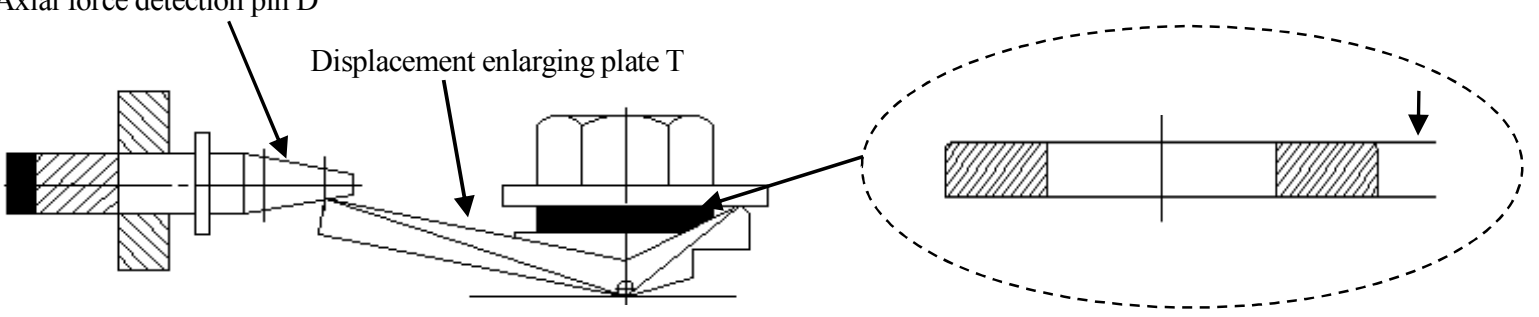

(a) Maximum protrusion of axial force detection pin D.

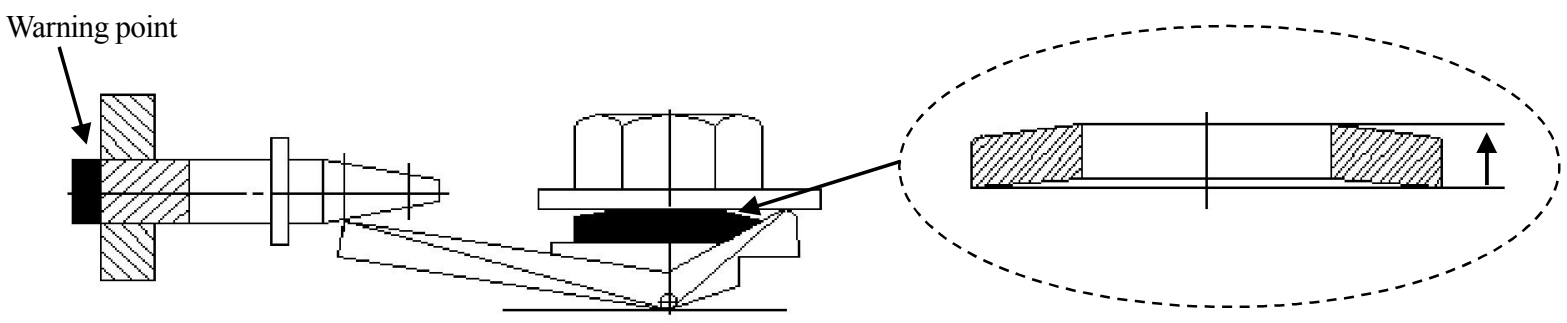

(b) Retightening request warning.

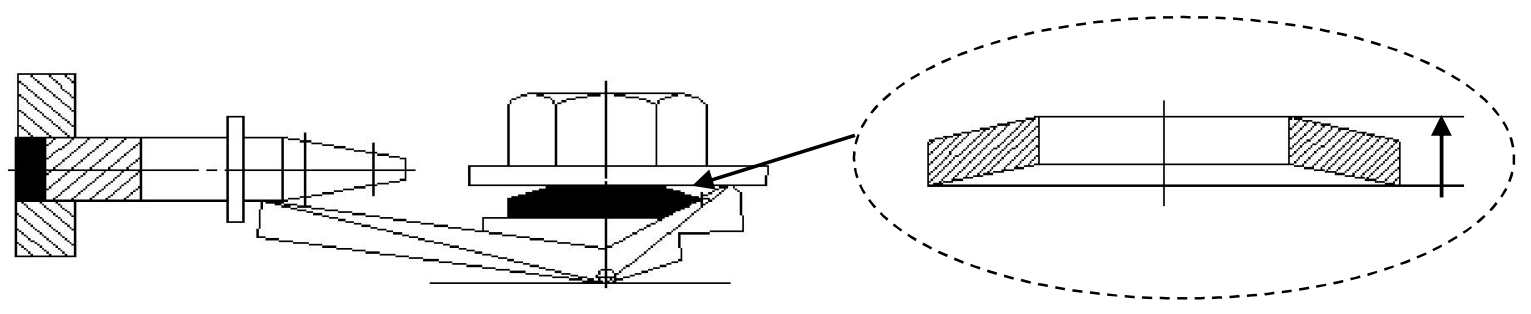

(c) Minimum permissible axial force.

Fig. 3 Relationship between magnified displacement of conical spring washer $\mathrm{W}$ and axial force detection pin $\mathrm{D}$. 
一方, 緩みの過程には, 皿ばね座金 $\mathrm{W}$ を最大許容軸力まで締め付けた状態と最小許容軸力による増し締め要求 警告点をそれぞれ上限，下限とするしきい值が存在し，このしきい值内でのボルト V の緩みの状態が検出ピン $\mathrm{D}$ に現れるように構成される，変位拡大板 $\mathrm{T} に は ， \mathrm{~A}$ 点を押し上げる方向に重力が働く．さらにこれを補助する圧 縮コイルばね 1 が組み込まれ，圧縮力 $\mathrm{F}_{1}$ が上向きに作用している，検出ピン $\mathrm{D}$ に圧縮コイルばね 2 が組み込ま れ, 変位拡大板 $\mathrm{T}$ と接触する $\mathrm{C}$ 点のテーパ部に $\mathrm{F}_{2}$ の力が作用し, 常時変位拡大板 $\mathrm{T}$ を押し戻す. なお, 可視化 機構は，重力の影響を考慮して水平使用が基本だが，重力に依存しない配置となるために圧縮コイルばね 1 の大 きな圧縮力が考慮される.

図 2 に皿ばね座金 $\mathrm{W}$ の構造を示寸(日本工業規格, 2001). 基本的に皿ばね座金 $\mathrm{W}$ の密着変位 $\mathrm{W}_{1}$ からの復元変 位を用いて, ボルト Vの緩みを拡大して可視化する機構である. 可視化機構は, 最大許容軸力と最小許容軸力の しきい值を設定し，軸力不足となる前に対策を行う増し締め要求警告点を設けている.

図 3 は皿ばね座金 $\mathrm{W}$ の変位と検出ピン D の突出状態を示したものでる. 図3(a)は皿ばね座金 $\mathrm{W}$ を最大許容軸 力 $\mathrm{A}$ 点まで締め付けた状態で, 検出ピン $\mathrm{D}$ は $\mathrm{S}$ 線まで突出している。このときの皿ばね座金 $\mathrm{W}$ は密着している 状態である. 図3(b)は最小許容軸力(危険)になる前の増し締め要求警告点の状態である. また, 図 3(c) は最小許容 軸力を下回った場合の危険な状態を示す．このとき皿ばね座金 W は大きく復元している．ボルト V が緩むと， 皿ばね座金 $\mathrm{W}$ は復元され，その復元変位は座金押さえ板 $\mathrm{P}$ に伝わり，変位拡大板 $\mathrm{T} の \mathrm{~A}$ 点は自重，圧縮ばね 1 の復元力 $\mathrm{F}_{1}$, 圧縮ばね 2 の復元力 $\mathrm{F}_{2}$ により上昇し, 反対に $\mathrm{C}$ 点は降下する. そのとき検出ピン $\mathrm{D}$ は圧縮コイル ばね 2 の復元力 $\mathrm{F}_{2}$ により, テーパ部を滑りながら押し戻される.つまり，ボルト V が締まっていて安全な場合は 検出ピン D が突出し，突出していない場合は緩んだ状態(危険)であることを示している.

\section{2 - 2 軸力検出ピンD の変位}

図 4 に, ボルトが緩んだときの可視化機構の動作を示す.ボルトV が緩むと, 座金押さえ板 P が上方に微小量 $\Delta \mathrm{Z}$ 変位する.このとき変位拡大板 $\mathrm{T}$ は反時計まわりに $\Delta \theta$ 回転し, 検出ピン $\mathrm{D}$ は $\Delta \mathrm{X}$ 変位する. 図 4 より式(1), 式(2)が得られる.

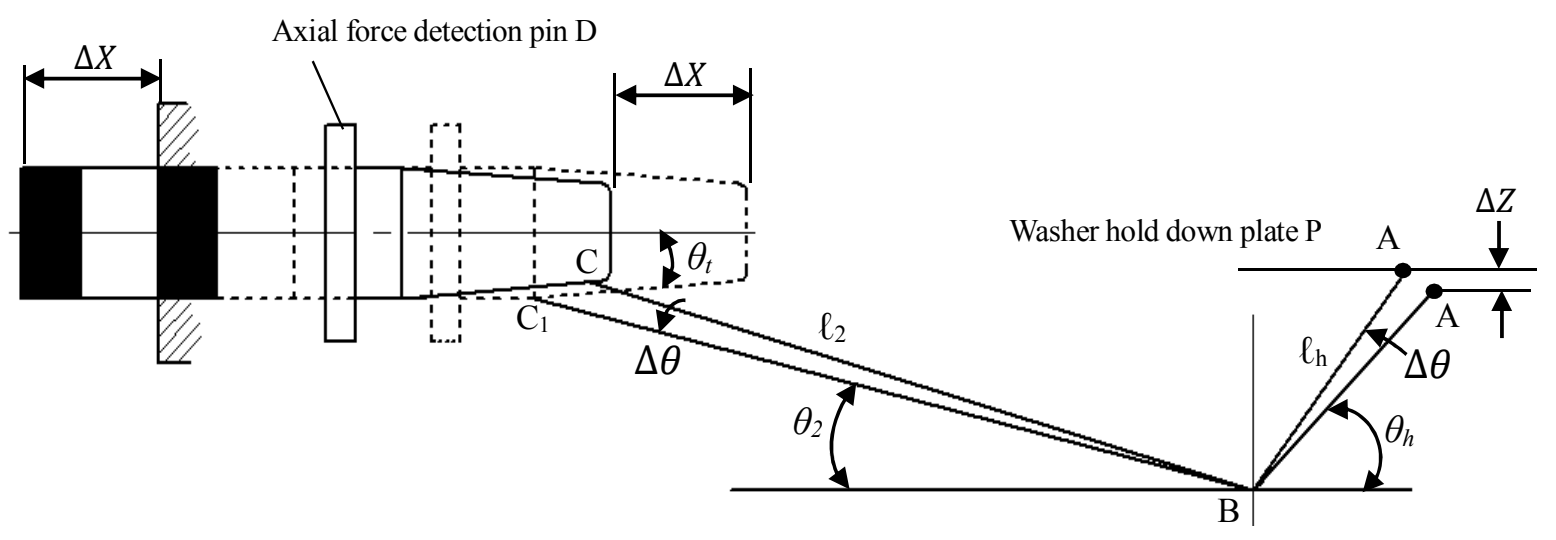

Fig. 4 Operation when the bolt is loose.

$$
\Delta Z=\ell_{h} \sin \left(\theta_{h}+\Delta \theta\right)-\ell_{h} \sin \theta_{h}
$$

$$
\Delta X \sin \theta_{t}=\ell_{2} \sin \left(\theta_{t}+\theta_{2}\right)-\ell_{h} \sin \left(\theta_{t}+\theta_{2}+\Delta \theta\right)
$$


ここで， $\Delta \mathrm{Z}$ は緩みによる変位， $\Delta \mathrm{X}$ は軸力検出ピン $\mathrm{D}$ の変位， $\ell_{h}$ は $\mathrm{AB}$ 間の長さ， $\ell_{2}$ は $\mathrm{BC}$ 間の長さ, $\theta_{t}$ はテーパ 角, $\Delta \theta$ は変位拡大板 $\mathrm{T}$ の回転角である. $\cos \Delta \theta \approx 1$ と近似すると, 式(1), 式(2)より次式が求まる. 緩みによる変 位 $\Delta \mathrm{Z}$ は，変位拡大板 $\mathrm{T}$ の形状と検出ピン D のテーパ角によって決まる倍率で拡大される.

$$
\Delta X=\frac{\ell_{2} \cos \left(\theta_{t}+\theta_{2}\right)}{\ell_{h} \sin \theta_{t} \cos \theta_{h}} \Delta Z
$$

\section{$2 \cdot 3$ 変位拡大板 $\mathrm{T}$ に働くカ}

ボルト $\mathrm{V}$ を締め付けると，座金押さえ板 $\mathrm{P}$ を介して変位拡大板 $\mathrm{T}$ に力 $\mathrm{F}_{\mathrm{h}}$ が加わる. 図 5 に変位拡大板 $\mathrm{T}$ に働 く力を示す.ここでは, $\ell_{h}$ 《 $\ell_{2}$ であるため, 重心は $\ell_{2}$ 上で支点から $\ell_{2} / 2$ の位置にあると近似する. また, 圧縮コ イルばね 1 の復元作用点は $\ell_{h}$ 上にあると近似する．変位拡大板 $\mathrm{T}$ は座金押さえ板 $\mathrm{P}$ の変位に応じて $\mathrm{B}$ 点を支点 に運動し, 検出ピン D のテーパ部と接触する. 変位拡大板 $\mathrm{T}$ には, 重力, 圧縮コイルばね 1,2 からの力が働く. B 点まわりに作用するモーメントのつりあいは式(4)で表される.

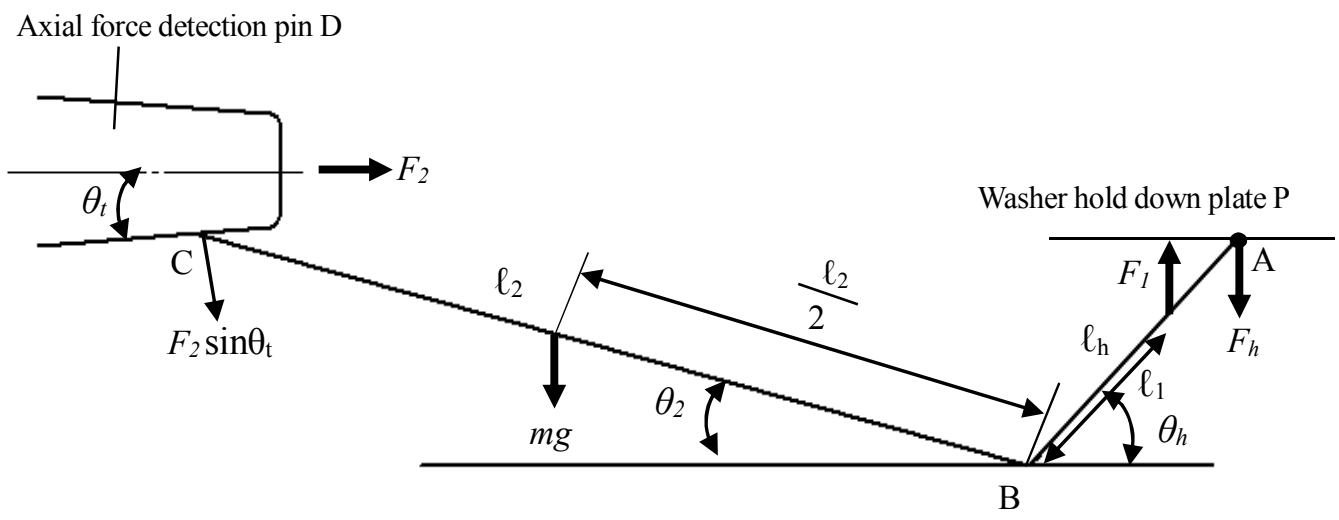

Fig. 5 Force acting on the displacement enlarging plate $\mathrm{T}$.

$$
\ell_{h} F_{h} \cos \theta_{h}=\ell_{2} F_{2} \cos \theta_{t} \cos \left(\theta_{t}+\theta_{2}\right)+\frac{\ell_{2}}{2} m g \cos \theta_{2}+\ell_{1} F_{1} \cos \theta_{h}>0
$$

一般に, $\theta_{t}+\theta_{2}<\pi / 2$ であり, 右辺の各項は全て正である. したがって常に座金押さえ板 $\mathrm{P}$ から変位拡大板 $\mathrm{T}$ を下げる方向に力 $\mathrm{F}_{\mathrm{h}}$ が働く. なお, 式(4)では各部の摩擦力を考慮していないが, 図 1 における検出ピン D $の \mathrm{~J}$ 部 及び $\mathrm{G}$ 部の摩擦力に対して $\mathrm{F}_{2}$ を大きく設計すること, 変位拡大板 $\mathrm{T}$ の摩擦力に対して, $\mathrm{F}_{1}$ や $\mathrm{F}_{2}$ をきく設ける 必要がある. それは, 経年劣化などによる検出ピンの固着, スティックなどの故障モードが発生したときに $\mathrm{F}_{1}$, $\mathrm{F}_{2}$ の力により誤ってボルトが締まっている信号を示すという検出ピンの危険側の誤りを防ぐためである.これは 安全確認型システムの条件であるノーマルクローズな構造の要求に応えるものである．また，ボルトを上下逆に 設置した場合は，式(4)の右辺第 2 項の符号が逆になる。この場合も， $\mathrm{F}_{1}, \mathrm{~F}_{2}$ を十分大きく設計すれば， $\mathrm{F}_{\mathrm{h}}$ を正に 保つことが可能である.

\section{3. 可視化機構の試作による検証}

\section{$3 \cdot 1$ 試作機構の仕様}

可視化機構の動作を検証するために, M16 ボルト(強度区分 4.8)に対して試作装置を製作した. M16 ボルトの標 準的締付力は $40 \mathrm{kN}$ である. 最大許容軸力を皿ばね座金の最大密着点とし, 最小許容軸力を $20 \mathrm{kN}$, 増し締め要 求警告点を $28 \mathrm{kN}$ とした。皿ばね座金は JIS 1 種重荷重用 H タイプを使用し，設置面の凸凹の影響をできるだけ 受けないようにするため，底面は側面を逃がしてあり，座金規格と同じ寸法と寸る試作品を得た．また，可視化 される検出ピンDの寸法は, IEC 80416-3 (IEC，2002)に示されている式(5)により決定した. 式(5)によって視距離 
$\mathrm{L}$ に対し，視覚的な明りょう度を維持できる寸法 $\mathrm{S}$ が与えられる. 本試作では，式(5)により視距離 $\mathrm{L}(\mathrm{mm})$ を 1000 $\mathrm{mm}$ として算出した結果, 視覚的な明りょう度を維持できる寸法 $\mathrm{S}(\mathrm{mm})$ は $10 \mathrm{~mm}$ 以上必要であることを示してい る.

$$
S=\frac{1}{100} L
$$

\section{$3 \cdot 2$ 皿ばね座金の特性}

ボルトを締めると軸力の増加に伴い座金押さえ板 P が変位する．この変位の主な原因は，ボルトの伸びと典ば ね座金の圧縮変位である. 図 6(a)は長さ $100 \mathrm{~mm}$ の M16 ボルト(強度区分 4.8)の軸力と伸び(理論值)である. また, 図 6(b)は今回使用した血ばね座金の軸力と圧縮変位の実測結果である。測定に使用した装置を図 6(c)に示す．座 金は JIS 1 種重荷重用 H タイプで呼び 16 である. 図 6(b)の(1)は皿ばね座金 W の圧縮工程，(2)はその復元工程， (3)は再び圧縮した工程である. (2)から(3)を5 回繰り返したデータを示している.ボルトVの緩みの可視化に用い るのは(2)の工程である. 同図の $\mathrm{a}_{2}$ 点は最大許容軸力点(密着点), $\mathrm{b}_{2}$ 点は増し締め要求警告点, $\mathrm{c}_{2}$ 点は最小許容軸 力点である. 皿ばね座金 $\mathrm{W}$ はボルトの呼び径に相応した $40 \mathrm{kN}$ 以上の軸力を持つ. また復元工程においては大き なヒステリシスが観測されるが，ボルト締め付け時に，緩みの監視の起点となる $\mathrm{a}_{2}$ 点の設定を人が正しく行えれ ば，再現性のある特性が得られることが確認されている.

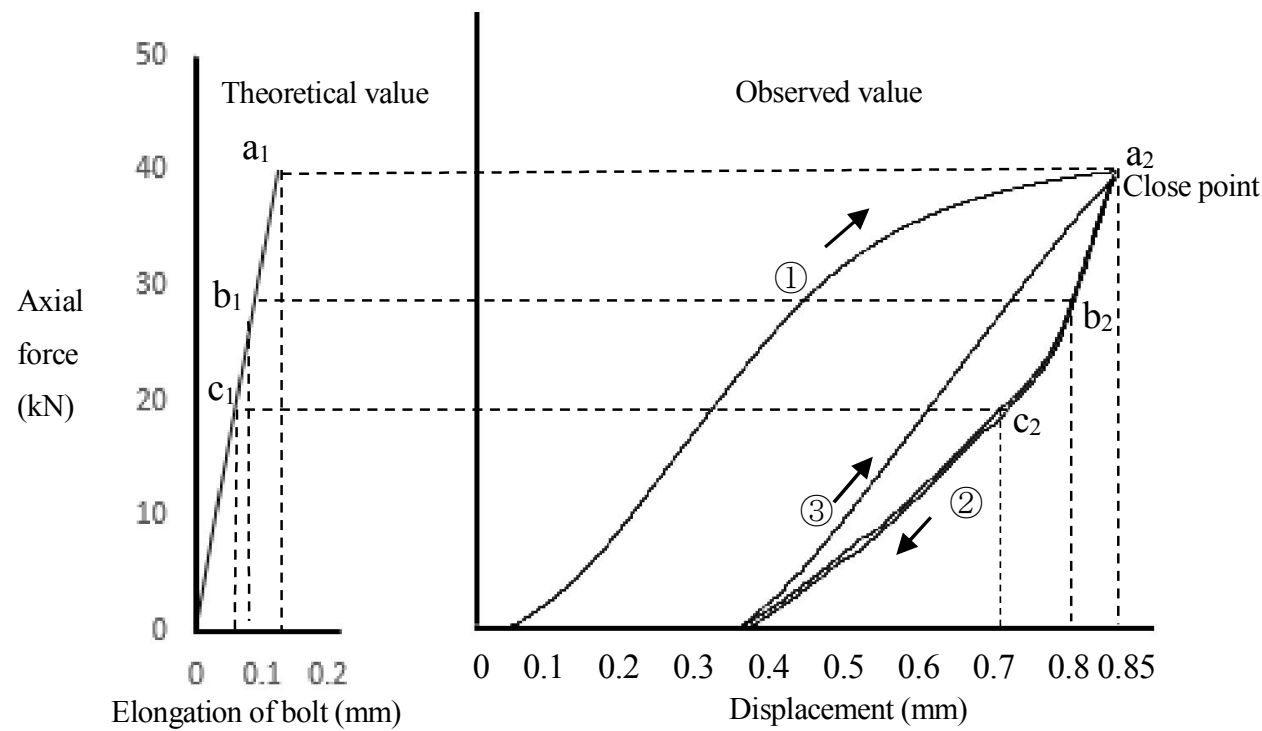

(a) Relationship between axial force and displacement of M16.

(b) Axial force and displacement of conical spring.

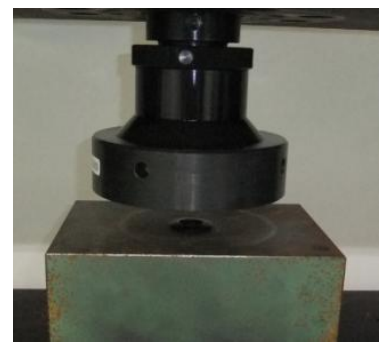

(c) Conical spring washer characteristics measurement.

(Bolt length $100 \mathrm{~mm}$ )

Fig. 6 Axial force and displacement of M16 bolt and conical spring washer.

\section{$3 \cdot 3$ 変位拡大板 $\mathrm{T}$ の寸法}

図 7 に試作に用いた変位拡大板 $\mathrm{T}$ と検出ピン $\mathrm{D}$ の主要寸法を示す。ボルト V を図 6(b)の $\mathrm{a}_{2}$ 点まで締め付けた 状態を示している. 図 8 は検出ピン D と軸力及び緩み変位の関係を示したものである. 式(3)より得られた関係を 図 8(a)に示し, 図 6(b) と式(3)より得られた軸力と検出ピン D の関係を図 8(b)に示す. 様々な外力によりボルト V

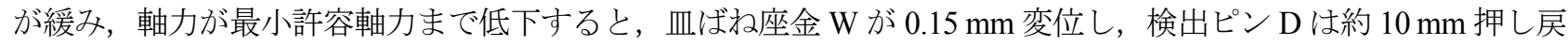
される. 増し締め要求警告点は約 $24 \mathrm{kN}$ に設定しており，このときの検出ピン D の突出量は $6 \mathrm{~mm}$ である. 最小 
許容軸力と増し締め要求警告点の位置は, 緩みの進行状態や締結の重要性など, 使用状況に応じて設定されるが, 変位拡大板 $\mathrm{T}$ の形状や寸法を変えず, テーパ角の異なる検出ピン D を挿入することにより対応が可能で互換性が ある。

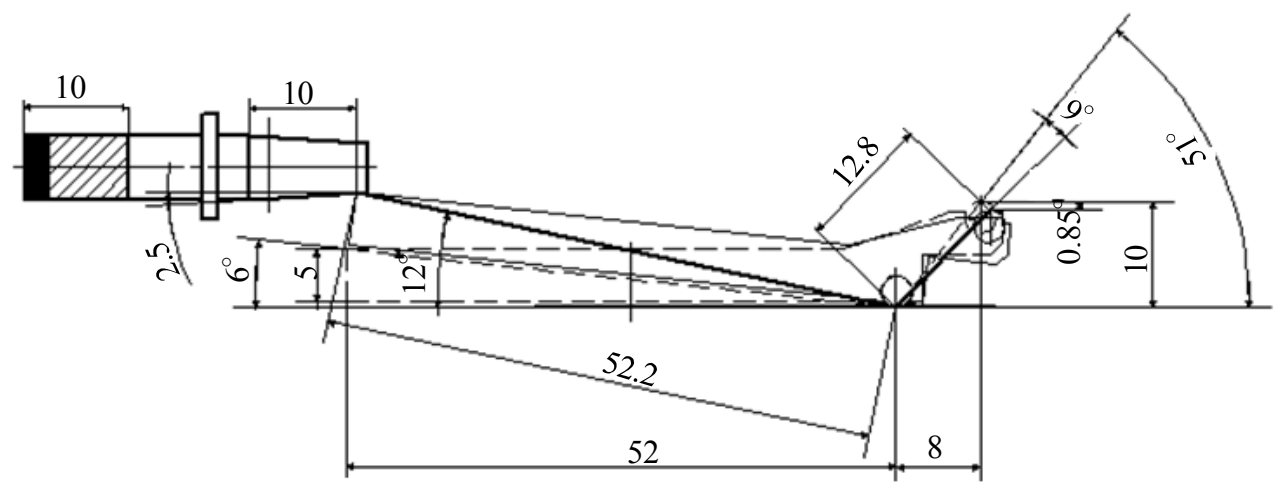

Fig. 7 Dimensions of displacement expansion plate $\mathrm{T}$ and detection pin $\mathrm{D}$ used for trial manufacture.

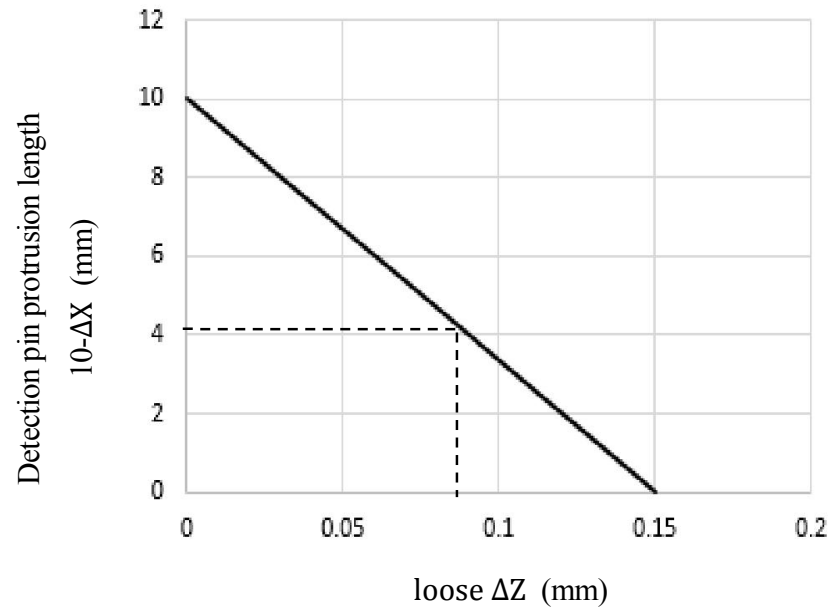

(a) Protruding length of pin $\mathrm{D}$ due to bolt loose.

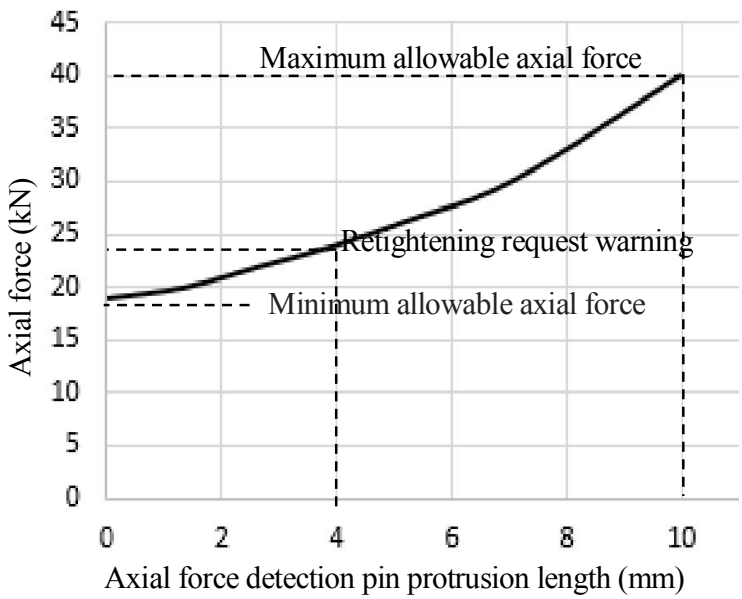

(b) Axial force and protrusion length of detection pin D.

Fig. 8 Relationship between detection pin $\mathrm{D}$ and axial force and loose displacement.

\section{4. 安全確認型システムの検証}

\section{$4 \cdot 1$ 安全確認型システムの条件}

安全確認型システムは「安全が確認できたときに限り運転を許可するシステム」である. システムで故障が原 因で安全確認ができないとき，システムが正常の状態に復帰されるまで運転が停止される．ここに，安全を確認 するためのセンサ(安全センサ)はフェールセーフであることが要求される. すなわち, 可視化機構は, ボルトの緩 み状態を監視する安全センサとしての役割のため, 検出ピン D は誤作動や動作不能などの不具合により「緩み」 の通報に混乱を来たす危険側の誤りは許されない，可視化機構を構成する部品は, 品質の保証が求められること 
は言うまでもないが，品質にはバラつきがあり，経年劣化，使用状況により故障や不具合が絶対には避けられな い.

一般に, 故障や不具合は認めるが，それが安全側誤り(非対称誤り)となる構成を要求するのが安全確認型シス テムである．非対称誤りの実現方法の 1 つに，重力を使用する方法がある．重力による引力を用いてエネルギー は必ず上から下へ落ちと決まっており, 水平上に設置された可視化機構は変位拡大板 $\mathrm{T}$ の自重により降下寸る. 既に述べたが，重力による非対称性の効果を補強する目的で圧縮コイルばね 1 が組み込まれている．さらに，圧 縮コイルばね 1 は回転防止ピンとの固着およびスティックなどの危険側誤りを考慮し自重とばねの力により変位 拡大板を降下させる構造としている. 同様に検出ピン D も圧縮コイルばね 2 により強制的に押し戻す機構として いる. また, 2.3 項においても変位拡大板 $\mathrm{T}$ の摩擦力よりも $\mathrm{F}_{1}$ および $\mathrm{F}_{2}$ を大きくしている. 設計段階において 「変位拡大板 $\mathrm{T}$ の摩擦力 $<\mathrm{F}_{1}$ および $\mathrm{F}_{2} 」$ としてばねの条件でノーマルクローズな構造を実現している．なお，ば ねの使用については，ISO 14119(ISO，2013)によると十分に吟味したコイルばねの使用に関して「入念に選定した 材料・製造・処理と，十分なガイドと，無負荷時のばね巻き間隔をワイヤー径より小さくし，破損時ばね力残留 の条件を備えるとき」十分に吟味したコンポーネントとしての資格を持つものと規定されている．これらに準拠 し，可視化機構は安全確認型システムの条件を満たす構成がなされている.

\section{$4 \cdot 2$ 可視化機構における情報エネルギーの流れ}

可視化機構としての特徵は, ボルト V の締め付けから検出ピン D の突出まで, 全て直接接触していること(機 械的結合)にある．可視化機構が示す安全な状態とは，ボルトV が締まっているとき検出ピン D が突出している ことで示される. 図9 は, 安全を「締め」とするポジティブな情報伝達を示す(安全技術応用研究会, 2004). 2 值 の論理変数 $\mathrm{N}$ で表し, 締まっている状態を論理值 1 , 緩んでいる状態を論理值 0 とし, 力の伝達による検出ピン $\mathrm{D}$ の状態を 2 值の論理変数 $\mathrm{R}$ で表し，検出ピン $\mathrm{D}$ が突出しているときを論理値 1 ，していないときを論理值 0 と するとき，この可視化機構の機能 $\mathrm{K}(\mathrm{N})$ に関して式(6)が成立しなければならない.

$$
R=K(N) \cdot K^{*}=N \cdot K^{*}
$$

$K^{*}$ はボルト V の締め付けから検出ピン D の突出に至る安全情報伝達の全体の動作状態を 2 值の論理変数(正常 時を論理值 1$)$ で示している. 図 9 は, 図 1 の構成要素の機能を $K_{1}, K_{2}, K_{3}, K_{4}, K_{5}, K_{6}$ とし, その動作状態をそ れぞれ $K_{1}^{*}, K_{2}^{*}, K_{3}^{*}, K_{4}^{*}, K_{5}^{*}, K_{6}^{*}$ としている. 同図はボルト V の締め付けから検出ピン $\mathrm{D}$ の突出に至る伝達の プロセスが各部の構成要素ごとに順次並べてあり, 各構成要素間で伝達するエネルギーの物理事象を示している. また, 変換するエネルギーの有無を 2 值の論理変数 $N_{1}, N_{2}, N_{3}, N_{4}, N_{5}$ として示している(エネルギーの存在を 論理值 1). この可視化機構で重要な点は, 構成要素がすべてポジティブ構成になっていることである.この理想 に従えば，図 9 に示すように，構成要素の出力 $N_{1}, N_{2}, N_{3}, N_{4}, N_{5}$ 及び $R$ は式(7)で示される.

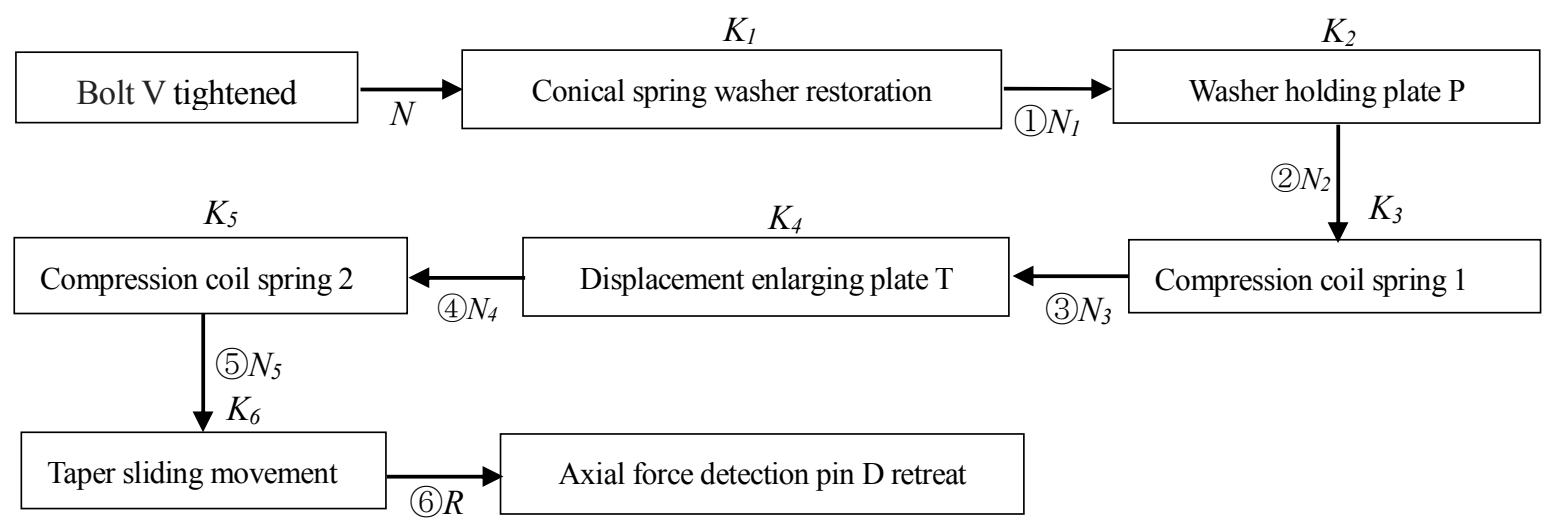

Fig. 9 Safety information flow diagram in case of bolt tightened. 


$$
\left.\begin{array}{l}
N_{1}=N \cdot K_{1}^{*} \\
N_{2}=N \cdot K_{1}^{*} \cdot K_{2}^{*} \\
N_{3}=N \cdot K_{1}^{*} \cdot K_{2}^{*} \cdot K_{3}^{*} \\
N_{4}=N \cdot K_{1}^{*} \cdot K_{2}^{*} \cdot K_{3}^{*} \cdot K_{4}^{*} \\
N_{5}=N \cdot K_{1}^{*} \cdot K_{2}^{*} \cdot K_{3}^{*} \cdot K_{4}^{*} \cdot K_{5}^{*} \\
R=N \cdot K_{1}^{*} \cdot K_{2}^{*} \cdot K_{3}^{*} \cdot K_{4}^{*} \cdot K_{5}^{*} \cdot K_{6}^{*}=N \cdot K^{*}
\end{array}\right\}
$$

すなわち，式(7)より式(6)に代えて式(8)を得る.

$$
R=N \cdot K_{1}^{*} \cdot K_{2}^{*} \cdot K_{3}^{*} \cdot K_{4}^{*} \cdot K_{5}^{*} \cdot K_{6}^{*}=N \cdot K^{*}
$$

また，安全情報の伝達に関してポジティブな論理的関係を規定する式(9)を得る(蓬原，杉本，1990).

$$
N \geq N_{1} \geq N_{2} \geq N_{3} \geq N_{4} \geq N_{5} \geq R
$$

2.1 項で述べたように，人間による締め付け作業は，検出ピン $\mathrm{D}$ を引き出した状態でボルト V を締め，最大許 容軸力の確認を行った後, 検出ピン D をそのテーパ部に揃えると説明した. このように, 安全を示す情報出力 $\left(\mathrm{N}_{5}\right)$ は人間の正しい操作 $\left(\mathrm{N}_{5}{ }^{*}\right)$ に依存する. これを怠れば $\mathrm{R}=0$ となって, 保全を要求する事態を解消できない. 可視化 機構は, 人間の正しい操作を条件として構成される安全確認型システムだということができる.

一方, 緩みに対して可視化機構として重要なことは，ノーマルクローズ型(構造)となっていることである. 緩み は図 9 の $\mathrm{N}=1$ で生ずるプロセスである.ボルト V が緩むと血ばね座金 $\mathrm{W}$ が復元され，座金押さえ板 $\mathrm{P}$ が上昇 し，それを圧縮コイルばね 1 の復元でさらに上に押し上げる。それにより変位拡大板 $\mathrm{T}$ は降下し圧縮コイルばね 2 の復元によりテーパ部が滑り移動し，検出ピン D が押し戻され，ボルトの緩みが確認される.

緩みの発生 $(\mathrm{N} \rightarrow 0)$ に対するノーマルクローズの情報伝達, 寸なわち, $\mathrm{N} \rightarrow 0 \therefore \mathrm{N}_{1} \rightarrow 0 \therefore \mathrm{N}_{2} \rightarrow 0 \therefore \mathrm{N}_{3} \rightarrow 0 \therefore \mathrm{N}_{4} \rightarrow 0 \therefore \mathrm{N}_{5}$ $\rightarrow 0$ となって, その結果, 「緩み」に対する保全の要求 $\mathrm{R}=0$ を通報する.このように, 可視化機構は, 「緩み(危険)」 を通報するばかりでなく，故障や不具合で危険を通報できない場合も，少なくとも「緩み」と判断すべきとき誤 って「緩みなし(安全)」の判断を生じない安全確認型システムの条件を満たしている.

\section{$4 \cdot 3$ 可視化機構の状態を表す論理変数}

表 1 はボルト V の締め付けの作用力を論理変数 $\mathrm{V}\left(\mathrm{F}_{\mathrm{h}}\right)$ で表し, この力が伝達されて検出ピン $\mathrm{D}$ を突出させる作 用力を論理変数 $\mathrm{D}(\mathrm{out})$ で表して, 両変数の論理值の意味を示している. また, 表 2 には表 1 の論理值の全ての組 み合わせを並べて，その組み合わせの意味を示している．表 2 の組み合わせのうちで， $\mathrm{V}\left(\mathrm{F}_{\mathrm{h}}\right)=\mathrm{D}($ out $)$ の関係は正 常な入/出力関係である. 同表で $\mathrm{V}\left(\mathrm{F}_{\mathrm{h}}\right)>\mathrm{D}($ out $)$ と $\mathrm{V}\left(\mathrm{F}_{\mathrm{h}}\right)<\mathrm{D}($ out $)$ の論理的関係は故障状態を表す. $\mathrm{V}\left(\mathrm{F}_{\mathrm{h}}\right)>\mathrm{D}($ out $)$ の関 係 $\left(\mathrm{V}\left(\mathrm{F}_{\mathrm{h}}\right)=1, \mathrm{D}(\right.$ out $\left.)=0\right)$ は，ボルト $\mathrm{V}$ が締まっているときの力が検出ピン $\mathrm{D}$ に作用しないのであるから，変位拡 大板 $\mathrm{T}$ の曲がりや破損，または検出ピン D の引っかかりなどが想定される.

$\mathrm{V}\left(\mathrm{F}_{\mathrm{h}}\right)<\mathrm{D}$ (out) $)$ 論理的関係 $\left(\mathrm{V}\left(\mathrm{F}_{\mathrm{h}}\right)=0, \mathrm{D}(\right.$ out $\left.)=1\right)$ は, ボルト $\mathrm{V}$ を締め付けていない(ボルトが緩んでいる)のに検 出ピン D が突出しているのであるから，圧縮コイルばね 1 及び圧縮コイルばね 2 の破損や検出ピン D の大きな 引つ掛かりが生じている場合である.この 2 つは故障状態を表しているが, $\mathrm{V}\left(\mathrm{F}_{\mathrm{h}}\right)>\mathrm{D}(\mathrm{out})$ の関係 $\left(\mathrm{V}\left(\mathrm{F}_{\mathrm{h}}\right)=1, \mathrm{D}(\right.$ out $)$ =0)は, 安全側故障であり, 検出ピン D が突出していないことを保全マンが確認すると直ちに保全されるからで ある. しかし，検出ピン D の引っかかりを考慮すると十分な長期に使用する安全センサに対する品質と管理が必 要であることは言うまでもない. よって, 表 2 の故障状態が許されない関係として, 図 1 のボルト V の締め付け 力が検出ピン D への伝達には式(10)が成立しなければならない. 


$$
V\left(F_{h}\right)>D(\text { out })
$$

Table 1 Meaning of the logical variables $\mathrm{V}\left(\mathrm{F}_{\mathrm{h}}\right)$ and $\mathrm{D}$ (out).

\begin{tabular}{c|c|l}
\hline \hline Logical variable & Logical value & \multicolumn{1}{c}{ Meaning of logical value } \\
\hline \multirow{2}{*}{$\mathrm{V}\left(\mathrm{F}_{\mathrm{h}}\right)$} & 1 & Bolt V is tightened. (Axial force occurrence.) \\
\cline { 2 - 3 } & 0 & Bolt V is loose. (No radial force is generated.) \\
\hline \multirow{2}{*}{$\mathrm{D}$ (out) } & 1 & Axial force detection pin D protrudes. \\
\cline { 2 - 3 } & 0 & Axial force detection pin D does not protrude. \\
\hline
\end{tabular}

Table 2 Logical relationship between protrusions of axial force detection pin D and applied axial.

\begin{tabular}{|c|c|c|c|c|c|}
\hline $\mathrm{V}\left(\mathrm{F}_{\mathrm{h}}\right)$ & $\mathrm{D}($ out $)$ & \multicolumn{2}{|c|}{ Meaning of logical value combination } & Operating state & Logical relationship \\
\hline 1 & 1 & $\begin{array}{l}\text { Bolt is tightened and the axial force } \\
\text { detection pin protrudes. }\end{array}$ & $\mathrm{V}\left(\mathrm{F}_{\mathrm{h}}\right)=\mathrm{D}($ out $)$ & \multirow{2}{*}{$\begin{array}{l}\text { Normal operation } \\
\text { state. }\end{array}$} & \multirow{2}{*}{$\begin{array}{l}\qquad \mathrm{V}\left(\mathrm{F}_{\mathrm{h}}\right)=\mathrm{D}(\text { out }) \\
\text { Rational relationship. }\end{array}$} \\
\hline 0 & 0 & $\begin{array}{l}\text { Bolt is loose and the axial force } \\
\text { detection pin does not protrude. }\end{array}$ & $\mathrm{V}\left(\mathrm{F}_{\mathrm{h}}\right)=\mathrm{D}($ out $)$ & & \\
\hline 1 & 0 & $\begin{array}{l}\text { Bolt is tightened but the axial force } \\
\text { detection pin does not protrude. }\end{array}$ & $\mathrm{V}\left(\mathrm{F}_{\mathrm{h}}\right)>\mathrm{D}$ (out) & $\begin{array}{l}\text { Safety side } \\
\text { failure. }\end{array}$ & Permitted relationship. \\
\hline 0 & 1 & $\begin{array}{l}\text { Bolt is loose and the axial force } \\
\text { detection pin protrudes. }\end{array}$ & $\mathrm{V}\left(\mathrm{F}_{\mathrm{h}}\right)<\mathrm{D}$ (out) & $\begin{array}{l}\text { Dangerous side } \\
\text { failure. }\end{array}$ & $\begin{array}{l}\text { Unacceptable } \\
\text { relationship. }\end{array}$ \\
\hline
\end{tabular}

\section{$4 \cdot 4$ 可視化機構の考察}

ボルト V の緩みの可視化機構を構築する上で 2 機構の方法が考えられる. その 1 つは図 3 に示す今回採用し た方法でボルト V が緩んだとき検出ピン D が押し戻される方式と，もう 1 つは図 10 に示すように緩んだときに 突出する方法がある.どちらも機能的には同じ役割を果たすが, 空間の障害物により検出ピンDがみえない場合, 図 3 の方式では, 緩んだと判断され保全がされる. それに対して, 図 10 ではボルトV $\mathrm{V}$ が緩んでいるにもかかわ らず, 検出ピン D が突出していないため, ボルトは締っていると判断され保全されない.このようにボルトVが 締っているか緩んでいるかわからない状態は, 安全工学上「不安」状態で「危険」と判断される.

この可視化機構は，常時信号を発信し続けなければならない特性を有しており，可視化される状態を維持しな ければならない. 本研究の可視化機構の要となる検出ピン D の作動は, 圧縮コイルばね 2 の「たり」や「引っ かかり」などの不具合を起こした場合, 検出ピン D の作動に不安が残る。「へたり」においては, 連続的に荷重 が作用寸るものではなく, 十分に吟味されたスプリングの使用と, 「引っかかり」はバリなどの徹底した品質管理 で対応できるものと考える. また，点検時の周期的な指による接触確認を励行するなど，管理点検に盛り込むこ とが考えられる。

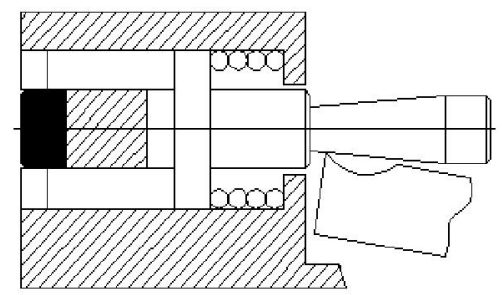

(a) Bolt tightening state.

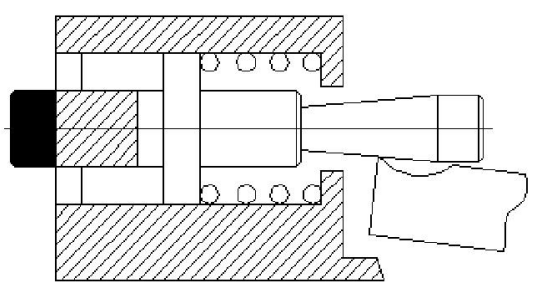

(b) Retightening request warning.

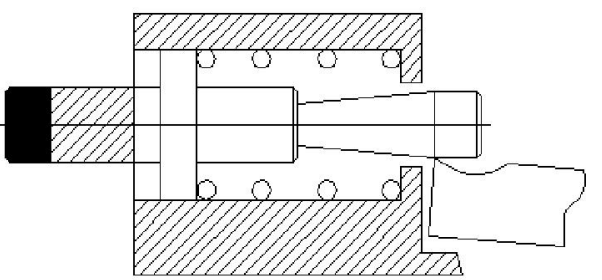

(c) Bolt loosened state.

Fig. 10 Operation of axial force detection pin. 
図 11 は本研究で試作された可視化機構である. 図 1 に示寸全体図は, 当初の設計に 2 箇所ほど修正を加えた ものである. 1 点目は締め付けの際，座金押さえ板 P の回り止めの役割をする回り止めピンを設けたこと， 2 点 目は検出ピン D の先端溝部をなくしストレートに変更してある.これは検出ピン D の動作をスムーズにするた めである.
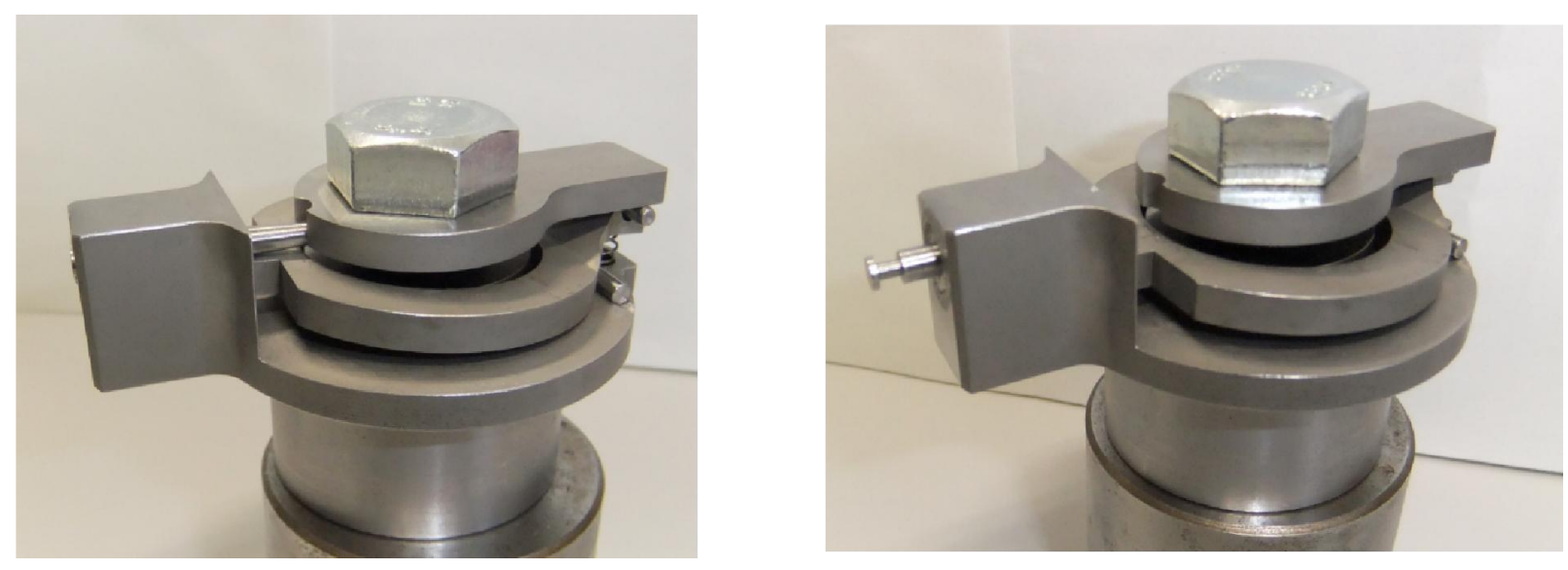

Fig. 11 Visualization mechanism of trial product.

\section{5. 結 言}

本研究では，ボルト緩みの正確かつ能率的な目視点検のために，安全確認型のボルト緩みの可視化機構を開発 した．本機構によれば，ボルトの締結状態を適切に管理でき，事故防止に貢献できるものと考える．本研究にお いて得た主たる結論は以下の通りである。

（1）提案する機構を用いれば，ボルトの締め付けトルクを変位の目視により確認できる，一般的なボルトの 締め付け管理は, トルクレンチが多く使用される. トルクレンチでは座面精度, ねじ面粗さなどのトルク 係数が関与し，軸力にバラツキがでるが，提案する機構ではこのようなバラツキは少ない.

（2）提案する皿ばね座金と変位拡大板を用いた機構により，軸力を可視化することができる．M16 ボルトの 試作機構では, 約 $20 \mathrm{kN}$ の軸力の変化によって生じた皿ばね座金 $0.06 \mathrm{~mm}$ の変位を, 約 170 倍に拡大し, 検出ピン D が $10 \mathrm{~mm}$ 変位することを確認した. これにより, $1000 \mathrm{~mm}$ の距離から視認が可能である.

（3）軸力のしきい值を変えるには, 検出ピン D のテーパ部角度を任意に変えることで, 検出ピン D 突出長さ が調整できる. 特に重要とされる締結では, 最大許容軸力と最小許容軸力の狭域の自由な選定ができる.

（4）安全工学上，可視化機構はボルト緩み発見の重要な安全センサ的役割を持っている. これらを実現する 上で不変的な重力の利用(非対称誤り特性)之, 十分に吟味されたスプリングを用いたノーマルクローズな 構造を用いた構成となっており, 安全確認型システムが形成されている.

\section{文献}

千葉正伸，笹川宏之，中村瑞穂，岡部眞幸，杉本旭，てこによる変位拡大機構を用いたボルトの緩み可視化座金 ユニットの開発，設計工学，Vol.52, No.2 (2017), pp.98-108, DOI:10.14953/jjsde.2016.2691.

蓬原弘一, 杉本旭, 安全確認形作業システムの論理的考察, 日本機械学会論文集 C 編, Vol.56, No.529 (1990), pp.2378-2385.

IEC80416-3:2002, 機器・装置用図記号の基本原則一第 3 部：図記号を使用するときの指針, 日本規格協会(2002).

ISO14119:2013，機械類の安全性 - ガードと共同するインタロック装置 - 設計及び選択のための原則, 日本規格協会(2013). 
JIS B1251:2001，ばね座金，日本工業規格 (2001), pp.12-13.

国土交通省，ホイール・ボルト折損による大型車の車輪脱落事故が増加，国土交通省報道発表資料， 平成 27 年 8 月 28 日 (2015).

(社)日本労働安全衛生コンサルタント会編, これからの安全技術 -工作機械等の制御機構のフェールセーフ化に 関するガイドラインの解説 (2000), pp.22-39.

安全技術応用研究会，安全基礎工学(安全機構築の基礎) (2004), pp.9-20.

杉本旭，蓬原弘一，安全の原理，日本機械学会論文集 C 編, Vol.56, No.530 (1990a), pp. 2601-2609.

杉本旭, 蓬原弘一, 安全制御系における安全情報のエネルギー伝達, 日本機械学会論文集 C 編, Vol.56, No.530 (1990b), pp. 2658-2665.

杉本旭,蓬原弘一,向殿政男,安全作業システムの原理とその論理的構造, 電気学会論文誌 D 編, Vol.107D, No.9 (1987), pp.1092-1098.

朝日新聞, 遊具のボルト落ち軽傷, 2012 年 4 月 30 日朝刊 (2012a).

朝日新聞, コースター、ボルト落下, 2012 年 12 月 6 日朝刊 (2012b).

若林克彦，「絶対」に緩まないネジの開発，日本機械学会誌, Vol.116, No.1141 (2013),pp.840-841.

\section{References}

Chiba, M. Sasagawa, H. Nakamura, M Okabe, M and Sugimoto, N., Development of visualization washer unit for detecting bolt loosening by using displacement magnification mechanism of lever type, Journal of japan society for design engineering, Vol.52, No.2 (2017), pp.96-106, DOI:10.14953/jjsed.2016.2691 (in Japanese).

Futsuhara, K. and Sugimoto, N., A logical consideration of the safety operation system of the safety confirmation type, Transactions of the Japan Society of Mechanical Engineers, Series C, Vol.56, No.529 (1990), pp.2378-2385 (in Japanese).

IEC80416-3, Basic principles for graphical symbols for use on equipment - Part3:Gudelines for the application of graphical symbols, Japanese standards association (2002) (in Japanese).

ISO14119, Safety of machinery - interlocking devices associated with guards-Principles for design and selection, Japanese standards association (2013) (in Japanese).

JIS B1251, Spring washer, Japanese Industrial Standards (2001), pp.12-13 (in Japanese).

Ministry of Land, Infrastructure, Transport and Tourism, Increase in wheel dropout accident of large cars due to breakage of wheel / bolt, Press Release, 28 August 2015 (2015) (in Japanese).

Occupational Safety and Health Consultancy, M, Future Safety Technology Central Labor Accident Prevention Association Explanation of guideline on fail-safe control mechanism of machine tool (2000), pp.22-39 (in Japanese).

Society of safety Technology and Application, Safety basic engineering (Foundation of construction of safety equipment) (2004), pp.9-20 (in Japanese).

Sugimoto, N. and Futsuhara, K., Principles of safety, Transactions of the Japan Society of Mechanical Engineers, Series C, Vol.56, No.530 (1990a), pp. 2601-2609 (in Japanese).

Sugimoto, N. and Futsuhara, K., Energy for safety information transmitted in safety control system, Transactions of the Japan Society of Mechanical Engineers, Series C, Vol.56, No.530 (1990b), pp. 2658-2665 (in Japanese).

Sugimoto, N., Futsuhara, K. and Mukaidono, M., The principle and logical structure of safety in man-machine system, Transactions on Electrical and Electronic Engineering, Series D, Vol.107D, No.9 (1987), pp.1092-1098 (in Japanese).

The Asahi Shimbun, Playground equipment bolts fell slightly, Morning edition on 30th April 2012 (2012a) (in Japanese).

The Asahi Shimbun, Coaster, bolt fall, Morning edition on 6th December 2012 (2012b) (in Japanese).

Wakabayashi, K., Developing never loosing nuts, Journal of the Japan Society of Mechanical Engineers, Vol.116, No.1141 (2013), pp.840-841 (in Japanese). 